\title{
O Processo de Construção de Abordagens Históricas na Formação Interdisciplinar do Professor de Matemática
}

\author{
The Process of Construction of Historical Approaches in Interdisciplinary \\ Training for Mathematics Teachers
}

\author{
Eliane Maria de Oliveira Araman \\ Irinéa de Lourdes Batista**
}

\begin{abstract}
Resumo
Este artigo apresenta os resultados de uma investigação a respeito da relevância que o processo de construção de abordagens históricas apresenta na formação do professor de Matemática, mais especificamente no que se refere à construção de saberes interdisciplinares. As investigações evidenciam que os conhecimentos teóricos e metodológicos da história da Matemática são importantes para a formação docente. Diante disso, nosso objetivo, neste artigo, é analisar e evidenciar como tais conhecimentos colaboram para a estruturação de saberes interdisciplinares do professor de Matemática. Para isso, entrevistamos seis professores que vivenciaram o processo de construção e aplicação de abordagens históricas em sala de aula e, por meio da análise de conteúdo, estruturamos categorias que evidenciam saberes que colaboram para a formação interdisciplinar do professor.
\end{abstract}

Palavras-chave: História da Matemática. Formação de Professores. Saberes Docentes. Análise de Conteúdo.

\begin{abstract}
This paper presents the results of an investigation about the importance of the process of building historical approaches has to the process mathematics teachers' formation, specifically in regard to the construction of interdisciplinary knowledge. The investigations show that the theoretical and methodological knowledge of history of mathematics are important for teacher education. Therefore, our objective was to analyze and show how these skills work together to structure interdisciplinary knowledge of the mathematics teacher who has experienced the process of construction and application of historical approaches in the classroom. To this end, we interviewed six teachers who had experienced this process and, by means of content analysis, we structured categories that show the knowledge developed by them and which contribute to interdisciplinary training of teachers.
\end{abstract}

Keywords: History of Mathematics. Teacher's Education. Teacher knowledge. Content Analysis.

\section{Introdução}

\footnotetext{
* Doutora em Ensino de Ciências e Educação Matemática pela Universidade Estadual de Londrina (UEL). Professora da Universidade Tecnológica Federal do Paraná (UTFPR), Cornélio Procópio, Paraná, Brasil. Endereço para correspondência: Avenida Alberto Carazzai, 1640, Bairro Centro, CEP: 86300-000, Cornélio Procópio/PR. E-mail: elianearaman@utfpr.edu.br.

** Doutora em Filosofia pela Universidade Federal de São Paulo (USP). Professora da Universidade Estadual de Londrina (UEL), Londrina, Paraná, Brasil. Endereço para correspondência: Rodovia Celso Garcia Cid, Km 380, s/n, Campus Universitário, CEP: 86051-990, Londrina/PR. E-mail: irinea@uel.br.
} 
As pesquisas que procuram compreender o processo de formação docente vêm atraindo, cada vez mais, a atenção e a preocupação da comunidade acadêmica. São várias vertentes a respeito das quais versam essas investigações, como, por exemplo, a formação inicial do professor, focada nos cursos de licenciatura, a necessidade de formação continuada, a investigação dos saberes e conhecimentos do professor necessários para sua função, a necessidade de reflexão da prática profissional, entre outros. É possível perceber um consenso entre as pesquisas no sentido de buscar compreender a complexidade de conhecimentos e saberes que os professores mobilizam visando superar os desafios diários que demandam as situações de ensino e de aprendizagem.

É nesta perspectiva que a presente investigação se insere. Em nossa compreensão, os saberes docentes têm origem em muitas fontes, como a formação inicial, a própria prática, os conhecimentos teóricos das diferentes áreas, a didática, as pesquisas educacionais, entre outros. Sendo assim, nosso objetivo foi compreender e explicitar algumas relações entre os conhecimentos teóricos e metodológicos advindos da história da Matemática e a construção dos saberes interdisciplinares do professor de Matemática.

Para alcançar esse objetivo, investigamos professores que vivenciaram a pesquisa, construção e aplicação de uma abordagem pedagógica, fundamentada na história da Matemática, de um dado conteúdo matemático. Por meio dos discursos desses professores e fundamentando-nos nos referenciais teóricos que subsidiam a pesquisa, procuramos estabelecer alguns elementos que evidenciam de que forma o processo de construção de abordagens históricas traz implicações para a construção dos saberes dos mesmos.

A presente pesquisa apresenta uma leitura diferenciada, uma vez que analisamos os discursos de professores que vivenciaram o processo de pesquisa, construção e aplicação de uma abordagem histórica. As compreensões alcançadas nesse estudo colaboram com elementos relevantes, evidenciados por meio da análise, que complementam a discussão dos saberes docentes, evidenciando o papel que o processo de construção de abordagens históricas tem no desenvolvimento de saberes interdisciplinares no professor.

\section{Saberes e conhecimentos necessários para a ação docente}

As atuais pesquisas a respeito da formação de professores têm chamado a atenção para a necessidade de compreensão da prática do professor, de como esse profissional desenvolve continuamente seus conhecimentos, num processo constante de ir e vir, a partir de suas experiências. As investigações que visam analisar os saberes que são mobilizados pelos 
professores durante a sua prática apresentam um grau de relevância, uma vez que buscam realizar a análise numa perspectiva de contribuição para as questões de formação de professor.

Para compreender as questões que envolvem os saberes docentes, realizamos um estudo teórico apoiados em pesquisas nacionais e internacionais que discutem essa temática, como Almeida e Biajone (2007); Brito e Alves (2008); Gauthier et al. (1998); Shulman (1986); Tardif (2002). As discussões versam sobre os diferentes saberes que os professores mobilizam e a importância dos mesmos para a sua atuação e desenvolvimento profissional.

De acordo com Shulman (1986), as questões que envolvem os conhecimentos do professor são muito complexas, necessitando de um arcabouço teórico coerente que compreendesse tais questões. Segundo seus estudos, as pesquisas de formação docente que ocorriam até então tinham como preocupação investigar como os professores organizavam e administravam suas turmas, as atividades, o tempo, as tarefas, seus planejamentos, entre outros. Dessa forma, na visão de Shulman (apud ALMEIDA; BIAJONE, 2007, p. 287) "essas pesquisas trivializam a prática pedagógica, ignorando assim sua complexidade e reduzindo suas demandas".

Shulman apresenta algumas reflexões acerca dos conhecimentos do professor:

Quais são os domínios e categorias de conhecimento do conteúdo na mente dos professores? Como, por exemplo, estão relacionados o conhecimento do conteúdo e o conhecimento pedagógico geral? De que forma são os domínios e categorias de conhecimentos representados nas mentes dos professores? Quais são as formas promissoras de aumentar a aquisição e o desenvolvimento de tal conhecimento? ${ }^{1}$ (SHULMAN, 1986, p. 9).

Em sua visão, questões como essas estavam sendo ignoradas nas investigações a respeito da formação e desenvolvimento profissional do professor. Assim, Shulman (1986) e seus colaboradores tentam abordar esses questionamentos em um programa de pesquisa que visa investigar como os conhecimentos de um professor são adquiridos, revistos e combinados, compondo uma base de conhecimentos (knowledge base).

Shulman (1986) sugere uma distinção entre três categorias de conhecimentos, quando se refere ao conhecimento da disciplina para ensiná-la: o conhecimento do conteúdo da disciplina (subject matter content knowledge), o conhecimento pedagógico do conteúdo da disciplina (pedagogical content knowledge), e o conhecimento do currículo (curricular

\footnotetext{
${ }^{1}$ Oferecemos ao leitor o texto original da citação: What are the domains and categories of content knowledge in the minds of teachers? How, for example, are content knowledge and general pedagogical knowledge related? In which forms are the domains and categories of knowledge represented in the minds of teachers? What are promising ways of enhancing acquisition and development of such knowledge?
} 
knowledge). Para ele, é na articulação entre essas três categorias que se forma a base de conhecimentos do professor.

Nos estudos desenvolvidos por Gauthier e seus colaboradores (1998), observamos a preocupação em considerar o contexto real em que o ensino efetivamente acontece para a construção dos saberes dos professores. Tais estudos procuraram identificar, nas pesquisas norte-americanas sobre o ensino, as convergências observadas no que se refere aos saberes mobilizados pelos professores na prática pedagógica (knowledge base $)^{2}$.

Os autores argumentam que é primeiramente necessário conhecer o processo de ensino para depois refletir sobre ele e que, "ao contrário de outros ofícios que desenvolveram um corpus de saberes, o ensino tarda a refletir sobre si mesmo" (GAUTHIER et al., 1998, p. 20). Em seus estudos, arrazoam que ainda temos pouca compreensão a respeito das atitudes dos professores em sala de aula e da influência que exercem na aprendizagem. Entretanto, conhecer esses aspectos "do saber profissional docente é fundamental e pode permitir que os professores exerçam o seu ofício com muito mais competência" (GAUTHIER et al., 1998, p. 20).

De acordo com Brito e Alves (2008), a profissionalização do ofício do ensino pressupõe a compreensão e descrição da natureza dos saberes que fundamentam a prática profissional do professor. Dessa forma, a partir da década de 1980, aproximadamente, observamos um ímpeto nas pesquisas com relação a compreender e descrever a ação docente por meio de investigações realizadas diretamente nas salas. Nesse contexto, as questões que envolvem os saberes, as habilidades e as atitudes que os professores mobilizam durante o exercício de sua profissão começam a ser debatidas. Assim,

[...] as inúmeras pesquisas realizadas nos últimos anos, com o objetivo de definir um repertório de conhecimentos para a prática pedagógica, podem ser interpretadas como uma série de incentivos para que o docente se conheça enquanto docente, como uma série de tentativas de identificar os constituintes da identidade profissional e de definir os saberes, as habilidades e as atitudes envolvidas no exercício do magistério (GAUTHIER et al., 1998, p. 18).

Os autores entendem que a profissionalização da atividade docente deve enfrentar o desafio de identificar os saberes próprios do ensino, considerando o contexto real, complexo, no qual muitas variáveis interferem no processo de ensino e nas tomadas de decisão do professor. Propõem um ofício feito de saberes, os quais "formam uma espécie de reservatório" que possibilita ao professor se abastecer para responder à diversidade de

\footnotetext{
${ }^{2}$ Gauthier et al. (1998) esclarecem que, em inglês, o termo knowledge base é empregado frequentemente em um sentido amplo, que engloba todos os saberes do professor, como os citados por Shulman. Em seus estudos, preferem utilizar a expressão repertório de conhecimentos para designar o que chamam de saberes da ação pedagógica.
} 
questões que envolvem o ensino (GAUTHIER et al., 1998, p. 27). Esse reservatório, nos estudos apontados por Gauthier et al. (1998), é composto por seis tipos de saberes: saberes disciplinares; saberes curriculares; saberes das ciências da educação; saberes da tradição pedagógica; saberes da experiência e saberes da ação pedagógica.

Salientamos os saberes da ação pedagógica, que, segundo Gauthier et al. (1998) são os saberes da experiência quando se tornam públicos e são testados por meio das pesquisas realizadas em sala de aula. Os julgamentos que os professores fazem a respeito de suas experiências e os motivos que apoiam as suas tomadas de decisão podem ser estudados pelos pesquisadores, com a finalidade de estabelecer algumas regras de ação que podem ser conhecidas e aprendidas por outros. Os resultados de tais pesquisas podem trazer muitas contribuições para a formação docente, entretanto, o que observamos é que os saberes da ação pedagógica são pouco investigados, trazendo poucos benefícios para os programas de formação.

Tardif (2002), juntamente com seus colaboradores, procurou evidenciar a necessidade de investigações que analisem o professor como produtor de saberes. Em sua compreensão, os professores, no exercício da profissão, utilizam um leque de saberes para atender às suas necessidades de ensinar. Embora isso ocorra cotidianamente, eles apresentam dificuldades em “teorizar a sua prática e formalizar seus saberes" (TARDIF, 2002, p. 274). Como consequência, tais saberes são pouco explicitados e estudados, tornando-se pessoais, tácitos e intuitivos. No entendimento de Tardif (2002), o professor, no exercício de sua profissão, utiliza diversos saberes em sua prática diária, tais como os disciplinares; os curriculares; os profissionais; os pedagógicos e os saberes.

Os saberes docentes, como salientam Rocha e Fiorentini (2006, p. 156), são mobilizados no contexto da prática, "a partir dos problemas e desafios da prática - mediante mobilização e (re)significação de saberes adquiridos ao longo da vida", compreendendo não somente a dimensão prática, mas também são formados por elementos teóricos e conceituais da disciplina, das ciências da educação e das concepções que o professor carrega consigo do que é ser professor. Tardif (2002) salienta que os saberes docentes podem ser caracterizados por um sincretismo, uma vez que o professor apresenta um conjunto de conhecimentos, de atitudes, de concepções "que utiliza em sua prática, em função, ao mesmo tempo, de sua realidade cotidiana e biográfica e de suas necessidades, recursos e limitações" (p. 65).

A proposta de Tardif (2002) vai além de mostrar uma definição ou uma categorização dos saberes docentes. O autor advoga em favor de colocar o professor como sujeito do conhecimento e produtor de saberes, de forma que as pesquisas em formação docente devem 
considerar essa problemática. Em outras palavras, "a epistemologia da prática profissional sustenta que é preciso estudar o conjunto de saberes mobilizados e utilizados pelos professores em todas as suas tarefas" (TARDIF, 2002, p. 259).

As pesquisas em saberes docentes evidenciam a importância de um estudo sistematizado dos saberes mobilizados pelos professores durante a sua prática, de forma que esses saberes não fiquem restritos às experiências particulares de cada docente, mas que possam ser analisadas à luz das pesquisas científicas, e é com essa proposta que desenvolvemos nosso trabalho.

\section{A história da Matemática na formação docente}

É ampla a literatura que discorre a respeito da relevância dos conhecimentos da história da Matemática para a Educação Matemática. Encontramos um vasto campo de argumentos favoráveis à implementação de abordagens históricas nas aulas de Matemática, mas temos que analisar a formação do professor para tal. Autores como Bicudo (1999), Furinguetti (2007), Brito e Carvalho (2009), Bursal (2010), entre outros, consideram que os estudos históricos a respeito dos diversos tópicos de Matemática podem enriquecer o conhecimento do professor e, em consequência disso, sua atuação em sala de aula.

Consideramos que a história da Matemática, com seu enfoque epistemológico e metodológico, pode ser um fator contributivo para a formação de professores de Matemática, como já nos diz a literatura, mas especificamente, pode auxiliar o professor na estruturação de seus saberes docentes (ARAMAN; BATISTA, 2013). A integração entre a história da Matemática na formação inicial e também em serviço tem sido um tema de interesse internacional nas pesquisas nos últimos anos (FAUVEL; MAANEN, 2000). O seu uso nos contextos educacionais exige reflexão didática, já que o docente precisa estar preparado para isso.

De acordo com as pesquisas realizadas, a inserção de elementos históricos trazem benefícios para a formação do professor de Matemática, em diversos aspectos. Uma dessas contribuições se dá em relação à compreensão da natureza do conhecimento matemático. Em nossos estudos teóricos - Bicudo (1999), Charalambous, Panaoura e Philippou (2009), Barbin (2000), Bursal (2010) - pudemos perceber que muitos professores não apresentam uma compreensão adequada da sua ciência, no caso, a Matemática. Apresentam a noção de um corpo de conhecimentos pronto, acabado, no qual não há revisões a serem feitas. Apresentam também a noção de uma ciência de caráter empírico, em que as interpretações são feitas 
apoiadas nas observações. Também têm a concepção de que os conteúdos, teorias, leis, entre outros, são "descobertos" por pessoas geniais, com pouca colaboração entre os pares. Além disso, concebem uma ciência livre de influências sociais, culturais e políticas.

Outro aspecto salientado pelas pesquisas é que a história da Matemática pode contribuir para a compreensão dos conteúdos matemáticos. Ao estudar um determinado conceito, a partir de uma abordagem histórica, o professor pode caminhar para uma compreensão de como aquele conceito foi sendo desenvolvido, quais os elementos conceituais necessários para a sua compreensão, quais são os pontos de maior dificuldade, por que eles foram importantes naquela época, por que são importantes hoje, quais eram as necessidades para o desenvolvimento daquele dado conceito, entre outros - Batista e Luccas (2004), Miguel (2005), Matthews (1995), Bursal (2010), Brito e Carvalho (2009), Furinguetti (2007).

Essa compreensão extrapola aquela recebida durante a sua formação, ocasionando um entendimento mais amplo e significativo do conteúdo matemático, o que trará benefícios para suas aulas. Ao desenvolver um conteúdo com seus alunos, o professor pode oferecer muito mais do que fórmulas e exercícios, desde que ele tenha conhecimento para isso.

Encontramos ainda pesquisas que indicam que a história da Matemática contribui para formação metodológica do professor. Ao elaborar uma abordagem histórica para ensinar algum conteúdo matemático, o professor precisa ter cuidados metodológicos, só que de caráter pedagógico, como adequar o material histórico ao nível de desenvolvimento dos seus alunos, ao tempo disponível para tal, certificar-se de que a proposta colabore efetivamente para a aprendizagem, entre outros - Dass (2005), Fried (2008), Cury e Motta (2008), Carvalho (2000).

Ao se propor a desenvolver abordagens históricas com seus alunos, o professor utiliza conhecimentos que vão além dos históricos ou dos conceituais relacionados ao conteúdo. Ele utiliza também conhecimentos pedagógicos vindos de estudos teóricos e também de sua prática, a fim de tornar factível o uso daquelas informações históricas em sala de aula.

Outra discussão que encontramos indica que a história da Matemática colabora com a visão interdisciplinar do professor. A questão da interdisciplinaridade ${ }^{3}$ vem sendo muito debatida na comunidade acadêmica, que ressalta a necessidade da superação daquela visão compartimentada das áreas do conhecimento. A história da Matemática já guarda em si esse

\footnotetext{
${ }^{3}$ Segundo Lavaqui e Batista (2007), a conceituação de interdisciplinaridade não apresenta uma definição estável, associada a diferentes concepções epistemológicas. Salientamos que, nessa pesquisa, a compreensão que temos de interdisciplinaridade refere-se às interações possíveis e existentes entre duas ou mais disciplinas, cuja interação pode ir desde a simples comunicação de ideias até a integração mútua de conceitos, promovendo enriquecimentos mútuos.
} 
caráter interdisciplinar. Temos, num eixo, o estudo histórico e suas especificidades; em outro encontramos as questões filosóficas; e ainda temos o eixo relativo ao conhecimento matemático e suas características, que são diferentes de outras ciências. Então, trabalhar com história da Matemática já pressupõe uma postura interdisciplinar.

Além disso, os estudos históricos proporcionam uma visão mais ampla do conhecimento matemático, em contraste com a visão especializada - e por vezes compartimentada - da formação inicial. Essa visão permite que o professor, por meio dos estudos históricos, observe as relações existentes entre as várias áreas do conhecimento científico e como os conhecimentos de uma área podem contribuir para o desenvolvimento de outras. Muitas vezes, o professor não consegue perceber esse caráter interdisciplinar da ciência, e os estudos históricos podem contribuir para isso - Batista (2009), Tzanakis e Arcavi (2000), Grugnetti e Rogers (2000).

Mas ainda é importante, e fundamental, salientar a interface com os conhecimentos pedagógicos do professor. Ao estudar e desenvolver uma abordagem histórica para o ensino, o professor percebe a necessidade da aproximação de todas essas áreas, como já nos referimos nas questões metodológicas. De acordo com Batista, Lavaqui e Salvi (2008), a condução de uma prática educativa interdisciplinar apresenta elementos próprios, diferentes das práticas interdisciplinares da pesquisa científica. No entendimento desses pesquisadores, as práticas interdisciplinares presentes na educação escolar "revelam alguns aspectos característicos, tais como as finalidades a que se destinam; os objetos de estudos e as consequências que produzem”(BATISTA, LAVAQUI; SALVI, 2008, p. 211- destaques dos autores).

A figura que apresentamos a seguir procura sintetizar o caráter interdisciplinar da construção de uma abordagem histórica para o ensino de Matemática, que se dá por meio da articulação e integração de diversos conhecimentos oriundos da formação, cuja relação está representada pelas setas duplas: 


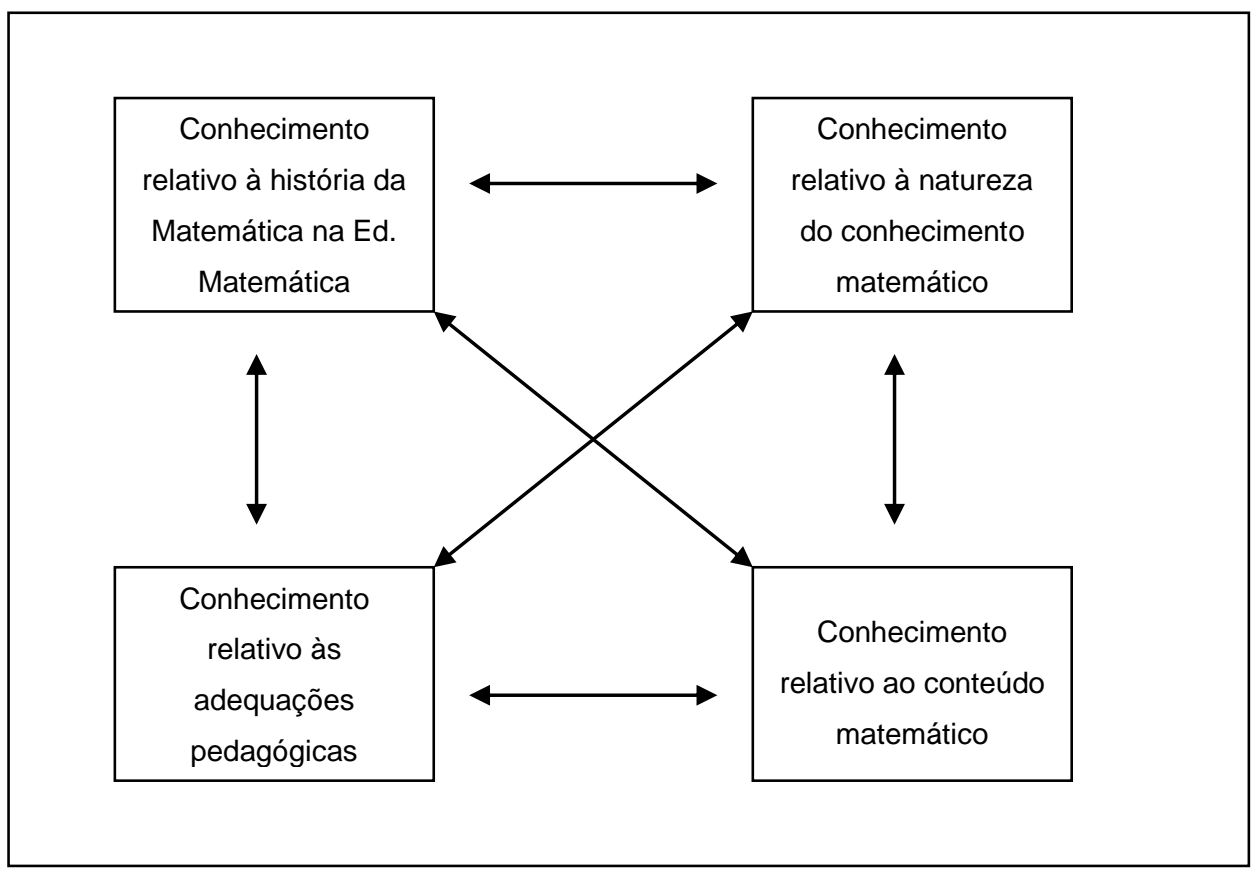

Figura 1: Caráter interdisciplinar da construção de uma abordagem histórica para o ensino de Matemática Fonte: Araman (2011).

Sendo assim, compreendemos que a elaboração de uma abordagem pautada na história da Matemática colabora para uma prática educativa interdisciplinar, na qual elementos advindos de áreas diversas precisam ser relacionados e adaptados com a finalidade de colaborar com a aprendizagem em sala de aula. Na perspectiva da presente pesquisa, consideramos que esses aspectos salientados são relevantes e contribuem para a estruturação dos diversos saberes do professor de Matemática. Entretanto, nosso foco é discutir as contribuições que o processo de construção de aplicação de abordagens históricas desempenha para o desenvolvimento dos saberes interdisciplinares, uma vez que, como já dissemos, tal processo requer a interação entre diversas áreas do saber.

\section{Metodologia}

Este estudo está inserido no âmbito de pesquisa qualitativa em Educação Matemática. Na concepção de Bogdan e Biklen (1994) e de Lüdke e André (1986), esse tipo de investigação apresenta uma natureza descritiva, na qual os pesquisadores têm um interesse maior no processo e nos seus significados do que nos resultados ou produtos. A partir dos estudos teóricos que realizamos e que já explicitamos na seção anterior, conseguimos definir alguns aspectos que evidenciam a relevância da história da Matemática para a formação dos saberes interdisciplinares do professor de Matemática. 
Para a coleta dos dados empíricos, utilizamos entrevistas semiestruturadas com seis professores que vivenciaram a experiência de construir e aplicar uma abordagem pedagógica, fundamentada na história da Matemática, em sala de aula. No entendimento de Fiorentini e Lorenzato (2007, p. 120), as entrevistas são vantajosas "pois permitem ao entrevistado fazer emergir aspectos que não são normalmente contemplados por um simples questionário" e permitem "correções, esclarecimentos e adaptações que a tornam sobremaneira eficaz na obtenção de informações desejadas" (LÜDKE; ANDRÉ, 1986, p.34). As questões versaram a respeito da formação dos professores, da atuação profissional dos mesmos, do interesse pela história da Matemática e sua utilização na Educação Matemática, do processo de pesquisa, construção e aplicação da abordagem histórica em sala de aula. Nosso objetivo foi, por meio das entrevistas, identificar como ocorreu o processo de articulação e adequação de conhecimentos oriundos de diversas áreas para a construção da abordagem histórica e de como tal empreendimento contribuiu para os saberes interdisciplinares do professor.

Elegemos como metodologia de análise de dados a análise de conteúdo, pois esta possibilita uma interpretação dos dados que "oscila entre os dois pólos do rigor da objetividade e da fecundidade da subjetividade” (BARDIN, 2004, p. 7). A análise de conteúdo busca a interpretação dos discursos por meio de uma análise sistematizada das comunicações.

Segundo Bardin (2004), a categorização é um processo estruturado que comporta duas dimensões: isolar os elementos (construção das unidades de registro) e classificá-los com a finalidade de organizar o material analisado (agrupar os elementos por analogia). Os temas são muito utilizados nas análises e podem ser compreendidos como afirmações acerca de um assunto, ou as ideias, enunciados, proposições, que sejam portadores de significações. Os temas são utilizados como unidades de registro "para estudar motivações de opiniões, de atitudes, de valores, de crenças, de tendências, etc.” (BARDIN, 2004, p. 99). Dessa forma, optamos por um processo de análise categorial temático.

A partir da transcrição das entrevistas, iniciamos o processo de análise dos dados à luz da análise de conteúdo, identificando unidades de registros e, a partir das similitudes dos discursos dos professores, conseguimos atingir uma compreensão da relevância que o processo de construção de abordagens históricas teve na construção dos saberes dos docentes envolvidos nesta investigação.

O processo de seleção dos sujeitos da pesquisa se deu pela adequação do perfil do professor que procurávamos com os objetivos da pesquisa. Os professores sujeitos do estudo deveriam ter vivenciado a experiência de desenvolver e aplicar abordagens direcionadas à aprendizagem, fundamentadas na história da Matemática. Por meio de um levantamento 
realizado em programas de Pós-Graduação na área de ensino de Ciências e Educação Matemática conseguimos localizar nos bancos de teses e dissertações 18 trabalhos com tais características, conforme Araman e Batista (2013).

Estabelecemos contato com vários autores das referidas pesquisas e conseguimos realizar entrevistas com seis deles, os quais concordaram, esclarecidamente, em participar de nossa pesquisa. Os professores que participaram da coleta de dados para a pesquisa e nos concederam entrevista foram designados por P1 (professor 1), P2 (professor 2) e assim sucessivamente, com a finalidade de preservar a identidade dos mesmos. O quadro a seguir apresenta uma síntese do perfil dos sujeitos participantes:

\begin{tabular}{|c|c|c|c|c|c|c|c|}
\hline \multirow{2}{*}{$\begin{array}{l}\text { Sujei } \\
\text { to }\end{array}$} & \multicolumn{4}{|c|}{ Formação } & \multirow{2}{*}{$\begin{array}{l}\text { Experiência } \\
\text { profissional }\end{array}$} & \multicolumn{2}{|c|}{ Proposta desenvolvida } \\
\hline & Graduação & $\begin{array}{l}\text { Especiali- } \\
\text { zação }\end{array}$ & Mestrado & Doutorado & & Conteúdo & $\begin{array}{c}\text { Nível de } \\
\text { ensino }\end{array}$ \\
\hline P1 & $\begin{array}{c}\text { Licenciatura } \\
\text { em Ciências } \\
\text { - Hab. } \\
\text { Matemática } \\
\text { CESULON- } \\
\text { PR } \\
\end{array}$ & $\begin{array}{l}\text { Educação } \\
\text { Matemática } \\
\text { UEL-PR }\end{array}$ & $\begin{array}{l}\text { Ensino de } \\
\text { Ciências e } \\
\text { Educação } \\
\text { Matemática } \\
\text { UEL-PR }\end{array}$ & $\begin{array}{c}\text { Ensino de } \\
\text { Ciências e } \\
\text { Educação } \\
\text { Matemática } \\
\text { (em curso) } \\
\text { UEL-PR } \\
\end{array}$ & $\begin{array}{c}\text { Aproximada- } \\
\text { mente } 16 \text { anos - } \\
\text { Ensino } \\
\text { Fund/Médio/ } \\
\text { Superior }\end{array}$ & $\begin{array}{c}\text { Sistemas } \\
\text { Lineares/ } \\
\text { Determinan- } \\
\text { tes/Matrizes }\end{array}$ & $\begin{array}{c}2^{\circ} \text { ano do } \\
\text { Ensino } \\
\text { Médio }\end{array}$ \\
\hline $\mathrm{P} 2$ & $\begin{array}{c}\text { Licenciatura } \\
\text { em Ciências } \\
\text { - Hab. } \\
\text { Matemática } \\
\text { FAFICOP- } \\
\text { PR }\end{array}$ & $\begin{array}{l}\text { Educação } \\
\text { Matemática } \\
\text { FAFICOP- } \\
\text { PR }\end{array}$ & $\begin{array}{l}\text { Ensino de } \\
\text { Ciências e } \\
\text { Educação } \\
\text { Matemática } \\
\text { UEL-PR }\end{array}$ & & $\begin{array}{l}\text { Aproximada- } \\
\text { mente } 8 \text { anos - } \\
\text { Ensino } \\
\text { Fund/Médio/ } \\
\text { Superior }\end{array}$ & $\begin{array}{l}\text { Funções } \\
\text { trigonomé- } \\
\text { tricas }\end{array}$ & $\begin{array}{c}2^{\circ} \text { ano do } \\
\text { Ensino } \\
\text { Médio }\end{array}$ \\
\hline P3 & $\begin{array}{c}\text { Licenciatura } \\
\text { em } \\
\text { Matemática } \\
\text { UFSC-SC }\end{array}$ & & $\begin{array}{l}\text { Educação } \\
\text { para a } \\
\text { Ciência e o } \\
\text { Ensino de } \\
\text { Matemática } \\
\text { UEM-PR }\end{array}$ & & $\begin{array}{c}\text { Aproximada- } \\
\text { mente } 4 \text { anos - } \\
\text { Ensino } \\
\text { Médio/Supe- } \\
\text { rior/ cursos } \\
\text { preparatórios/ } \\
\text { tutor de EAD }\end{array}$ & $\begin{array}{l}\text { Conceito de } \\
\text { função }\end{array}$ & $\begin{array}{l}8^{\text {a }} \text { série do } \\
\text { Ensino } \\
\text { Fundamen- } \\
\text { tal }\end{array}$ \\
\hline $\mathrm{P} 4$ & $\begin{array}{l}\text { Licenciatura } \\
\text { em } \\
\text { Matemática } \\
\text { UFPB-PB }\end{array}$ & $\begin{array}{l}\text { Ensino de } \\
\text { Matemáti- } \\
\text { ca } \\
\text { UFPB-PB }\end{array}$ & $\begin{array}{l}\text { Ensino de } \\
\text { Ciências } \\
\text { Naturais e } \\
\text { Matemática } \\
\text { UFRN-RN } \\
\end{array}$ & $\begin{array}{c}\text { Educação } \\
\text { Matemática } \\
\text { (em curso) } \\
\text { UNESP-SP }\end{array}$ & $\begin{array}{c}\text { Aproximada- } \\
\text { mente } 30 \text { anos - } \\
\text { Ensino } \\
\text { Fund/Médio/ } \\
\text { Superior } \\
\end{array}$ & $\begin{array}{l}\text { Secções } \\
\text { Cônicas }\end{array}$ & $\begin{array}{l}3^{\circ} \text { ano do } \\
\text { Ensino } \\
\text { Médio }\end{array}$ \\
\hline P5 & $\begin{array}{c}\text { Licenciatura } \\
\text { em } \\
\text { Matemática } \\
\text { UFPA-PA }\end{array}$ & $\begin{array}{l}\text { Ensino de } \\
\text { Ciências e } \\
\text { Matemáti- } \\
\text { ca } \\
\text { UFPA-PA }\end{array}$ & $\begin{array}{l}\text { Educação } \\
\text { UFRN-RN }\end{array}$ & $\begin{array}{l}\text { Educação } \\
\text { UFRN-RN }\end{array}$ & $\begin{array}{c}\text { Aproximada- } \\
\text { mente } 25 \text { anos - } \\
\text { Ensino } \\
\text { Fund/Médio/ } \\
\text { Superior } \\
\end{array}$ & $\begin{array}{c}\text { Trigonome- } \\
\text { tria }\end{array}$ & $\begin{array}{c}1^{\circ} \text { ano do } \\
\text { Ensino } \\
\text { Médio }\end{array}$ \\
\hline P6 & $\begin{array}{c}\text { Licenciatura } \\
\text { em } \\
\text { Matemática } \\
\text { UFRN - RN }\end{array}$ & & $\begin{array}{c}\text { Ensino de } \\
\text { Ciências } \\
\text { Naturais e } \\
\text { Matemática } \\
\text { UFRN/RN }\end{array}$ & & $\begin{array}{c}\text { Aproximada- } \\
\text { mente } 10 \text { anos - } \\
\text { Ensino } \\
\text { Fund/Médio/ } \\
\text { Superior/ } \\
\text { cursos } \\
\text { preparatórios/ } \\
\text { EJA }\end{array}$ & $\begin{array}{l}\text { Números } \\
\text { Complexos }\end{array}$ & $\begin{array}{c}3^{\circ} \text { ano do } \\
\text { Ensino } \\
\text { Médio }\end{array}$ \\
\hline
\end{tabular}

Quadro 1 - Síntese do perfil dos professores entrevistados

Fonte: Araman (2011).

\section{Apresentação e análise dos dados}


A análise foi desenvolvida agrupando as unidades por similitudes, conforme as categorias estruturadas na fundamentação teórica da pesquisa e explicitadas na figura 1 deste artigo. Sendo assim, identificamos nas entrevistas trechos que se enquadrassem em cada uma delas. O resultado obtido pode ser observado na sequência do texto.

- Categoria "Conhecimento relativo à história da Matemática na Educação Matemática”

Essa categoria evidencia a presença de conhecimentos relacionados às potencialidades do uso da história da Matemática na formação do professor que vivenciou o processo de construção de uma abordagem pedagógica baseada na história da Matemática. É fundamental que o professor, além de ter contato com estudos históricos a respeito do conteúdo matemático selecionado para a construção da abordagem, bem como dos fundamentos metodológicos relacionados à pesquisa histórica, como o uso de fontes, a seleção de episódios, entre outros, tenha a percepção das contribuições que os estudos históricos podem ter para a aprendizagem matemática. Observem alguns exemplares no quadro a seguir:

\section{Categoria "Conhecimento relativo à História da Matemática na Educação Matemática"}

\begin{tabular}{|c|c|}
\hline P1 & $\begin{array}{l}\text { Então, na reconstrução, havia determinadas situações em que você percebe que } \\
\text { historicamente os matemáticos ficaram enroscados vinte anos em determinado assunto. Se os } \\
\text { matemáticos ficaram enroscados vinte anos, é possível que no momento em que você estiver } \\
\text { ensinando aquele conteúdo, os alunos apresentem dificuldades nele. }\end{array}$ \\
\hline
\end{tabular}

Aprender a técnica é importante, a técnica, o método é importante, mas só isso não basta para o ensino de matemática. É importante contextualizar e a história ajuda muito.

Hoje eu percebo que para ensinar trigonometria é preciso saber muito mais do que as relações fundamentais, as funções trigonométricas. $\dot{E}$ preciso mostrar aos alunos a importância desse conhecimento, por que ele está presente até hoje nos currículos, como e por que ele se desenvolveu, qual a relação dele com outros conteúdos, etc. Isso a história me ajudou.

[...] eu procurei inicialmente identificar o que era cada palavra daquelas, seno, cosseno, dentro do contexto histórico porque a gente sabe que na matemática principalmente vem do latim, vem do árabe, vem de outras civilizações. Então eu queria entender e mostrar para o aluno o que significava cada palavra daquela referente às funções trigonométricas, mas de forma contextualizada e não apenas só a memorização dos nomes.

[...] usar alguns aspectos de como foi descoberto um conceito matemático, pode facilitar o entendimento do aluno, visto que, apresentar um conceito já formalizado, pronto e acabado, pode dificultar a aprendizagem e tornar a matemática algo dogmático.

Em certos momentos, a apresentação dedutiva é extremamente necessária. Mas o que não pode ocorrer é o professor ficar só nisso, não saber contextualizar o conhecimento para seu aluno, não conseguir explicar por que aquele conhecimento é importante, em que ele contribui, por que ele surgiu, e isso quase nunca é feito.

A História da Matemática melhora isso, contribui para o professor justificar, contextualizar, dar significado a esses conteúdos. 


\begin{tabular}{|c|c|}
\hline P4 & $\begin{array}{l}\text { Boa parte das minhas aulas se diferenciavam dos meus colegas professores, como já te falei, } \\
\text { mas mesmo assim elas se diferenciavam porque eu usava atividades dinâmicas, } \\
\text { experimentos, investigaçôes, etc. Mas ainda sentia falta de encontrar um sentido para os } \\
\text { conteúdos, de justificar perante meus alunos por que aqueles conteúdos matemáticos eram } \\
\text { importantes, em que contexto eles foram construídos, se os pesquisadores da época tiveram } \\
\text { ou não dificuldades, com quais outros conhecimentos eles se relacionam, etc. Então eram } \\
\text { dúvidas da própria matemática, quer dizer, da construção do conhecimento matemático que, } \\
\text { às vezes, uma atividade dinâmica ou um experimento por si só não davam conta também de } \\
\text { responder. E a história me ajudou muito nisso. } \\
\text { [...] eu usei apenas algumas atividades históricas, mas me chamou a atenção o fato de que } \\
\text { essas atividades históricas conseguiram contextualizar um pouco esse conhecimento } \\
\text { matemático e o aluno entendeu um pouco disso. Quer dizer, o contexto histórico traz } \\
\text { algumas compreensôes que não são possíveis apenas por meio de atividades experimentais. }\end{array}$ \\
\hline P5 & $\begin{array}{l}\text { [...] começamos a perceber a importância que a história tem, principalmente quando } \\
\text { começamos a entender melhor o desenvolvimento dos conceitos matemáticos, podendo dar } \\
\text { uma explicação melhor para os alunos. } \\
\text { [...] a história pode esclarecer conceitualmente a gente e na medida em que ela nos esclarece } \\
\text { conceitualmente, ela nos abre a possibilidade de uma reformulação do nosso exercício } \\
\text { docente. } \\
\text { Um outro exemplo do que chamou a atenção foi sobre ângulos, sobre uma ideia que tem lá } \\
\text { que fala de minuto e segundo, isso também chamou a atenção deles porque era uma } \\
\text { curiosidade que eles relacionaram com a contagem do tempo e a medida do ângulo que era } \\
\text { na base sessenta, então eles gostaram dessa informaçâo, pois era um assunto que eles já } \\
\text { conheciam, mas que foi contextualizado pela história. }\end{array}$ \\
\hline $\mathrm{P} 6$ & $\begin{array}{l}\text { Hoje eu compreendo que para ensinar matemática precisa muito mais do que saber o } \\
\text { conteúdo, o professor tem que conhecer novas estratégias de ensino, precisa compreender } \\
\text { como seu aluno aprende e a história da matemática me mostrou algumas possibilidades. } \\
\text { Busquei na história esses elementos que mostrassem o contexto no qual os números } \\
\text { complexos foram criados, qual era a necessidade disso, o que estavam pesquisando, como } \\
\text { eles foram sistematizados, em que eram aplicados, etc. } \\
\text { Buscamos uma maneira de tornar esse conteúdo contextualizado historicamente e que isso } \\
\text { facilitasse a aprendizagem dos alunos. }\end{array}$ \\
\hline
\end{tabular}

Quadro 2 - Discursos que remetem à categoria "Conhecimento relativo à História da Matemática na Educação Matemática"

Fonte: Araman (2011).

Todos os professores apresentaram alguns elementos que indicam as contribuições que a pesquisa em história da Matemática trouxe para a sua formação e para a sua ação docente. Para P1, a sequência histórica de evolução dos conceitos pode ser mais adequada para o processo de ensino, pois os alunos podem ter mais facilidade e interesse se os conteúdos forem apresentados segundo a ordem histórica de seu desenvolvimento. Chama a atenção também para o fato de que os estudos históricos podem indicar pontos de dificuldades na aprendizagem e aponta, como contribuição, o fato de que, ao saber disso, o professor pode ter mais cuidado com seus alunos. 
P2 esclarece que percebeu que ensinar trigonometria vai além de ensinar as relações fundamentais, as funções trigonométricas, e essa percepção foi possibilitada pelos estudos históricos. Afirma ainda que esse fato está influenciando a sua atuação em sala de aula. No entendimento de P3, a história possibilita uma alternativa de compreensão diferenciada em relação ao ensino tradicional e que pode auxiliar na compreensão dos alunos. Para ele, essa percepção colaborou para sua formação, considerando-se um professor mais bem preparado.

O discurso de $\mathrm{P} 4$ é muito interessante, pois este professor relata que já buscava em sua ação docente elementos diferenciados para abordar os conteúdos matemáticos, como o uso de experimentos, atividades de investigação, entre outros. No entanto, aponta que mesmo essas atividades diferenciadas não conseguiam dar algumas justificativas e explicações em relação aos conhecimentos. E indica a investigação histórica como uma contribuição para complementar a prática diferenciada que realizava.

Para P5, o entendimento do conteúdo por meio da história permite ao professor dar explicações mais adequadas para seus alunos. Acrescenta, como contribuição, que a compreensão dos conteúdos possibilitada pela história permite ao professor reformular a sua ação docente. P6 discorre a respeito da possibilidade que a história oferece de colocar o aluno em uma situação similar àquela ocorrida no contexto histórico. Acrescenta também que os estudos históricos que fez sobre os números complexos permitiu que ele tivesse uma atuação mais adequada junto aos alunos. Ainda aponta a história como uma opção para o processo de ensino de Matemática.

Os dados revelam que os professores atribuem à história da Matemática a capacidade de contextualizar os conteúdos matemáticos e que essa contextualização é importante para o processo de ensino e de aprendizagem.

P1 compreende que a abordagem pela história auxilia a contextualização do conteúdo, colaborando para que o aluno aprenda além das técnicas. P2 aponta que a terminologia usada na Matemática pode também ser favorecida por meio da abordagem pela história, uma vez que os alunos podem conhecer os contextos nos quais os termos foram criados e não apenas memorizá-los. Além disso, coloca que a contextualização histórica colabora para a compreensão dos conceitos e para o reconhecimento da importância dos mesmos.

Os trechos de P3 e P6 evidenciam a necessidade de contextualização dos conteúdos para a percepção da importância deles, das contribuições que eles trouxeram para a Matemática e para outras áreas, e que essas compreensões podem colaborar para a aprendizagem. P4 retoma a discussão a respeito das atividades experimentais, dizendo que a 
contextualização possibilitada pela história favorece algumas compreensões que as atividades experimentais, sozinhas, não favorecem.

E P5 nos coloca que o contexto histórico colaborou também no sentido de os alunos compreenderem algumas noções que já tinham, como a base sessenta, mas que foi contextualizada pela história na explicação sobre ângulos abordada na trigonometria.

Por meio da análise que realizamos, pudemos observar que a proposição de uma abordagem de ensino diferenciada, como a pautada na história da Matemática, requer alguns cuidados metodológicos que foram observados pelos professores. Como o objetivo de qualquer abordagem de ensino é proporcionar aprendizagem, os professores mostraram essa preocupação, de que a proposta que desenvolveram colabore, com elementos consistentes, para a aprendizagem matemática.

Encontramos essa discussão feita por muitos pesquisadores que evidenciam as potencialidades pedagógicas do uso da história da Matemática em sala de aula - Fauvel e Maanen (2000); Brolezzi (2003); Miguel e Miorim (2008), entre outros. Segundo eles, a abordagem dos conteúdos matemáticos via história tem potencialidades pedagógicas que devem ser aproveitadas pelos professores.

Os professores desenvolveram uma abordagem com finalidades pedagógicas, ou seja, com a finalidade de ensinar determinado conteúdo ou conceito. Os conceitos são trabalhados via abordagem histórica, como uma alternativa metodológica para a Educação Matemática. Essa maneira de conceber a inclusão da história da Matemática nos processos de ensino e de aprendizagem é apontada por Fried (2008) como a estratégia da acomodação.

Essa compreensão, a nosso ver, foi possibilitada pelo fato de os professores terem contato com os aportes teóricos da história da Matemática na Educação Matemática. Esse entendimento pode ter sido proporcionado por meio dos estudos teóricos que realizaram.

Vimos que as pesquisas que envolvem as discussões a respeito das potencialidades pedagógicas da história da Matemática atribuem a ela a capacidade de contextualizar os conteúdos, uma vez que realizar a contextualização não é uma tarefa trivial para os professores.

Segundo Matthews (1995), a história pode colaborar para a "superação do 'mar de falta de significação' que se diz ter inundado as salas de aula de ciências, onde fórmulas e equações são recitadas sem que muitos cheguem a saber o que significam" (MATTHEWS, 1995, p. 165).

Bicudo (1999), Miguel e Miorim (2008), Brito e Carvalho (2009), entre outros, consideram que a formação inicial recebida pelos professores muitas vezes não favorece a 
capacidade de justificar e contextualizar os conteúdos matemáticos em sala de aula. Os estudos históricos podem contribuir para minimizar essa dificuldade dos professores.

Esse fato foi evidenciado também pelos sujeitos, que perceberam que a história da Matemática colabora para a compreensão contextualizada dos conteúdos trabalhados. Pelos resultados obtidos nesta categoria, consideramos que os professores que tiveram contato com as pesquisas na área de história da Matemática na Educação Matemática, tiveram a oportunidade de desenvolver o entendimento das potencialidades que ela pode ter no processo de ensino e de aprendizagem, que vão além da abordagem da história como curiosidade ou motivação.

\section{- Categoria "Conhecimento relativo à natureza do conhecimento matemático"}

Já argumentamos, apoiadas nas pesquisas científicas, que o entendimento dos professores acerca da natureza do conhecimento matemático precisa ser melhorado e que os estudos históricos podem ser relevantes para isso - Batista e Luccas (2004); Matthews (1995); Martins (2007); Liu (2009).

Sendo assim, considerando que os sujeitos desta pesquisa tiveram a oportunidade de estudar o desenvolvimento histórico de um conteúdo matemático, nossa intenção foi analisar, nesta categoria, se os mesmos explicitam, de alguma forma, contribuições da história da Matemática para a compreensão da natureza do conhecimento matemático. Os resultados encontrados podem ser observados a seguir:

\begin{tabular}{|c|c|}
\hline \multicolumn{2}{|r|}{ Categoria "Conhecimento relativo à natureza do conhecimento matemático" } \\
\hline P1 & $\begin{array}{l}\text { [...] eu mudei radicalmente de uma visão passiva da matemática para uma visão } \\
\text { completamente dinâmica. } \\
\text { E a história faz com que a gente perceba isso, que para um conceito chegar aonde ele } \\
\text { chegou foi necessário muito trabalho, muita dedicação, colaboração entre muitas pessoas, } \\
\text { pessoas reais, que erram, que acertam. Foi bem interessante, para mim foi muito } \\
\text { interessante[...]. } \\
\text { Então isso muda aquela visão de mito, pois muita gente trabalha e contribui para que aquela } \\
\text { teoria fique cada vez mais concisa, consistente. }\end{array}$ \\
\hline $\mathrm{P} 2$ & $\begin{array}{l}\text { A reconstrução histórica foi me mostrando, a cada dia que eu achava algo novo nos livros, } \\
\text { nas fontes, que a matemática não estava pronta e acabada, mas que ela tinha uma evolução } \\
\text { [...]. } \\
\text { [...] a reconstrução histórica me ajudou a entender essa evolução da ciência, do } \\
\text { desenvolvimento da matemática, da trigonometria. }\end{array}$ \\
\hline P3 & $\begin{array}{l}\text { A pesquisa histórica nos faz perceber que o conhecimento matemático não é pronto e } \\
\text { acabado, mas que se desenvolve em um processo dinâmico. } \\
\text { Isso mudou, percebi que o caminho é o caminho da investigação, das tentativas, do uso dos } \\
\text { conhecimentos já estruturados por outros na formaçâa dos novos conhecimentos [...]. } \\
\text { Também tem a questão da criação de mitos, que a história me ajudou a compreender que os }\end{array}$ \\
\hline
\end{tabular}




\begin{tabular}{|c|c|}
\hline & $\begin{array}{l}\text { conhecimentos matemáticos são frutos de erros, acertos, de muito trabalho, de anos de } \\
\text { pesquisas, de dedicação. }\end{array}$ \\
\hline $\mathrm{P} 4$ & $\begin{array}{l}\text { [...] a pesquisa histórica me auxiliou nessa compreensão, quer dizer, pude viajar até o ano } \\
600 \text { a.C. e vir pouco a pouco montando uma história que, especificamente, desconhecia. Essa } \\
\text { pesquisa contribuiu para que eu compreendesse o desenvolvimento da matemática de uma } \\
\text { outra forma, de um modo dinâmico, com acertos, erros, avanços, etc. } \\
\text { Tinha aquela noção de mito que é passada para nós durante toda a nossa vida escolar, lei de } \\
\text { fulano, teorema de sicrano, essa visão vai mudando quando estudamos a história. E isso foi } \\
\text { importante para a minha compreensão e também para não dar uma compreensão errada } \\
\text { para meus alunos. }\end{array}$ \\
\hline P5 & $\begin{array}{l}\text { A matemática não é pronta e acabada pelo seguinte: se fosse, os matemáticos não estariam } \\
\text { mais produzindo mais matemática. Agora, essa consciência a gente só vai adquirindo na } \\
\text { medida em que a gente lê, a gente discute com outras pessoas, a gente ouve e a história me } \\
\text { ajudou muito nessa compreensão. } \\
\text { [...] a pesquisa histórica ajuda a ver que não é bem assim, um conhecimento para ser posto, } \\
\text { aceito, precisa passar por muitas contribuiçôes, não é tarefa de um único ser humano } \\
\text { extraordinário, fantástico. Isso a pesquisa possibilitou. }\end{array}$ \\
\hline P6 & $\begin{array}{l}\text { Hoje não, hoje eu tenho uma compreensão do conhecimento matemático bem diferente de } \\
\text { antes, e isso eu acho que contribuiu para a minha prática profissional. E isso foi possível } \\
\text { graças à pesquisa histórica. } \\
\text { [...] a história me fez perceber os fatos e os contextos em que os conceitos matemáticos } \\
\text { foram criados, a necessidade por que eles foram criados e ainda mais desmistificando aquela } \\
\text { velha visão de que os conceitos matemáticos nascem do nada, ou seja, me fez enxergar o } \\
\text { quão árdua e penosa é a criação de um conceito dessa natureza e que essa aquisição é um } \\
\text { esforço conjunto de várias pessoas ao longo de um vasto intervalo de tempo. }\end{array}$ \\
\hline
\end{tabular}

Quadro 3 - Discursos que remetem à categoria "Conhecimento relativo à natureza do conhecimento matemático"

Fonte: Araman (2011).

Pelos depoimentos dos professores, podemos observar que o contato que tiveram com a história da Matemática colaborou no sentido de proporcionar uma compreensão do conhecimento matemático como um processo dinâmico e em constante evolução. Todos os professores ouvidos afirmaram que esta visão de Matemática foi possível após os estudos históricos realizados por eles.

Na compreensão de Liu (2009), a Matemática comumente é vista como um corpo absoluto e rígido de conhecimentos, e a compreensão da natureza da Matemática pode ser impulsionada por meio de estudos históricos.

Nessa mesma perspectiva, Batista e Luccas (2004), Matthews (1995), Martins (2007), entre outros, apontam que os componentes históricos são relevantes para a formação docente, uma vez que podem colaborar para uma visão mais adequada do conhecimento científico. Nossa análise nos permite afirmar que, para este grupo de professores, os estudos históricos proporcionaram o entendimento da Matemática como um corpo de conhecimento dinâmico, cuja evolução se faz por meio da colaboração entre muitos pesquisadores, ao longo de muitos 
anos de dedicação, possibilitando novos e relevantes conhecimentos acerca da natureza do conhecimento matemático.

Para Liang et al. (2009), desenvolver uma compreensão adequada, por parte dos professores, acerca da natureza da ciência é uma tendência mundial. Assim, consideramos que o processo de construção de abordagens históricas vivenciado pelos professores, que envolveu estudos históricos, colaborou para o desenvolvimento de uma visão adequada da natureza do conhecimento matemático por parte dos mesmos.

Conforme Charalambous, Panaoura e Philippou (2009), a forma de o professor conceber a Matemática influencia a maneira como ele compreende o processo de ensino e de aprendizagem e, consequentemente, a sua ação pedagógica.

Segundo Dass (2005), existe uma relação entre a compreensão da natureza da ciência que o professor possui e sua atuação em sala de aula. Para Barbin (2000), a história pode colaborar para alterar a compreensão do próprio professor a respeito da Matemática. Esse fato pode influenciar no modo como ele ensina Matemática e, consequentemente, no modo como o aluno a compreende.

Em suma, a análise desta categoria nos permite perceber que a pesquisa realizada pelos professores colaborou com alguns elementos teóricos para a compreensão da natureza do conhecimento matemático, colaborando para a estruturação de saberes interdisciplinares. Essa compreensão, além de proporcionar ao professor um entendimento maior a respeito da área de conhecimento com a qual atua, pode trazer implicações para a sua atuação pedagógica.

\section{- Categoria "Conhecimento relativo ao conteúdo matemático"}

Encontramos na literatura discussões a respeito da formação conceitual do professor, que muitas vezes não é suficiente ou adequada para responder às demandas de uma sala de aula - Miguel (2005); Matthews (1995); Bursal (2010); Brito e Carvalho (2009); Furinguetti (2007).

Nesse sentido, nesta categoria consideramos as evidências apresentadas pelos professores de que a investigação histórica de um conteúdo matemático proporcionou um entendimento mais "profundo" do mesmo, uma compreensão voltada às justificativas, à explicitação dos porquês, dos debates, etc, que não tinham antes de realizar a pesquisa.

Todos os professores ouvidos alegaram que o contato que tiveram com o desenvolvimento histórico de dado conteúdo matemático proporcionou um tipo de compreensão diferente daquele que tinham até então. A compreensão a que se referem é aquela que extrapola a axiomatização e a aplicação mecânica dos conteúdos. 
Essa compreensão mais profunda é discutida por Brito e Carvalho que concordam que os estudos referentes à história da Matemática podem colaborar para esse entendimento:

\begin{abstract}
Entendemos "saber profundamente" em um sentido que vai além de o professor demonstrar com exatidão teoremas, lidar com linguagem matemática de um modo mecânico e ter algum conhecimento sobre quem e em que época tal teorema ou propriedade matemática "foi descoberta". Para nós o professor "saber profundamente Matemática" significa que além de conhecer teoremas, consegue relacionar diferentes campos desse conhecimento, refletir sobre os fundamentos da Matemática, perceber seu dinamismo interno e suas relações com outros campos do saber, transitar nos diferentes sistemas de registro de representação e, principalmente, entender o conhecimento matemático como um saber que coloca problemas e não apenas soluções (BRITO; CARVALHO, 2009, p. 15-16).
\end{abstract}

Dessa forma, os resultados da análise desta categoria podem ser observados no seguinte quadro:

\begin{tabular}{|c|c|}
\hline \multicolumn{2}{|r|}{ Categoria "Conhecimento relativo ao conteúdo matemático" } \\
\hline P1 & $\begin{array}{l}\text { Eu tive que estudar muita matemática para poder desvendar principalmente a teoria do } \\
\text { japonês (Seki Kowa), que tinha muito diagrama, muito quadrado, para saber o que } \\
\text { significava tudo aquilo, eu tive que aprender muita coisa, inclusive técnicas, métodos } \\
\text { matemáticos eu tive que aprender. }\end{array}$ \\
\hline $\mathrm{P} 2$ & $\begin{array}{l}\text { Percebi então que aumentou a minha capacidade de entendimento da matemática, do } \\
\text { conteúdo, de entender os porquês, de entender qual foi a importância, quais foram os fatos } \\
\text { marcantes, os impasses, o que estava acontecendo na época, que fenômenos eles estavam } \\
\text { descobrindo, para que a trigonometria foi importante e também para quais ciências a } \\
\text { trigonometria foi importante. }\end{array}$ \\
\hline P3 & $\begin{array}{l}\text { Então, na pesquisa histórica eu percebi que primeiro foi necessário a compreensão das } \\
\text { relações qualitativas de dependência, depois o uso de tabelas e da observação de } \\
\underline{\text { regularidades, as variáveis, somente depois disso veio a representação gráfica, a introdução }} \\
\text { da linguagem algébrica e a representação analítica. }\end{array}$ \\
\hline P4 & $\begin{array}{l}\text { Então, como o tema escolhido para ser desenvolvido foram as secções cônicas, eu precisei de } \\
\text { uma fundamentação histórica sobre tal. E foi muito bom fazer a parte histórica, me } \\
\text { esclareceu muitas dúvidas com relação a esse conteúdo. } \\
\text { Eu compreendi melhor os conceitos, nem tanto nos aspectos estruturais, do conhecimento } \\
\text { matemático em si, pois já o dominava, a estrutura eu já dominava, mas compreendi, por } \\
\text { exemplo, por que, historicamente, foi necessário realizar esses estudos, quais os problemas } \\
\text { que os matemáticos enfrentavam na época, quais eram os motivos que os moviam, etc. } \\
\text { [...] conheci alguns métodos de traçados utilizados ao longo da história, como traçados de } \\
\text { figuras cônicas em quadro perfurado utilizando o método do jardineiro (séc. VI), o método } \\
\text { de Kepler (usado já também no séc. VI). Então esse novo conjunto de compreensões que eu } \\
\text { tive sobre o assunto de secções cônicas foi a história que me proporcionou. }\end{array}$ \\
\hline P5 & $\begin{array}{l}\text { A história me possibilitou entender e explicar isso muito bem para o aluno, da ideia de } \\
\text { cosseno como seno reverso, da ideia de complementaridade entre seno e cosseno para } \\
\text { corresponder exatamente ao triângulo retângulo, explicar para o aluno que quando o seno } \\
\text { aumenta, o cosseno diminui e vice-versa. } \\
\text { Quando eu me deparei com a História mudou tudo, porque aí eu passei a entender } \\
\text { detalhadamente, por exemplo, uma coisa importantíssima na minha formação histórica e que } \\
\text { eu consegui passar para os meus alunos, que seno e cosseno são fragmentos do raio, todos }\end{array}$ \\
\hline
\end{tabular}




\begin{tabular}{|l|l|}
\hline & $\begin{array}{l}\text { aqueles valores da tabela correspondem a fragmentos do raio, que são exatamente as } \\
\text { projeçóes do raio nos eixos. }\end{array}$ \\
\hline P6 & $\begin{array}{l}\text { Logo, passei a encontrar algumas respostas bem razoáveis para esses questionamentos } \\
\text { exatamente com o uso da história da matemática, quer dizer, a história melhorou a minha } \\
\text { compreensão a respeito dos números complexos e isso me ajudou a dar algumas respostas } \\
\text { para os alunos. } \\
\text { [...] a pesquisa me ajudou muito na compreensão desse conteúdo (números complexos)! } \\
\text { A representação no plano cartesiano também foi bem interessante, porque sem a história } \\
\text { parece meio que uma regra meio que mecânica, mas só observando a formação desse } \\
\text { processo histórico é que vemos toda a dedução desse processo de formação que já vem de } \\
\text { outros conhecimentos mais consolidados como vetores o que também gera um maior poder } \\
\text { de compreensão. }\end{array}$ \\
\hline
\end{tabular}

Quadro 4 - Discursos que remetem à categoria "Conhecimento relativo ao conteúdo matemático" Fonte: Araman (2011).

O corpus analisado salienta que todos os professores perceberam que o contato que tiveram com desenvolvimento histórico dos conteúdos estudados por eles colaborou para a compreensão conceitual desses conteúdos e também no entendimento das razões, dos motivos pelos quais eles foram se desenvolvendo, da importância que os mesmos tiveram na época, da relação com outros conceitos, entre outros. Ou seja, uma compreensão que extrapola os aspectos estruturais e axiomáticos dos conteúdos em questão.

P1 esclarece que precisou de muitos estudos para compreender o raciocínio e as técnicas utilizadas na época e que, embora já conhecesse algumas delas, conseguiu ter uma compreensão de como foram estruturadas, qual era o raciocínio implícito em seu desenvolvimento e da importância delas no contexto de seu desenvolvimento e também no contexto atual.

Esses aspectos foram lembrados também por P2, que alega que a pesquisa histórica proporcionou um aumento em sua capacidade de entendimento da trigonometria. P3 salientou que esse estudo colaborou no sentido de demonstrar quais foram as etapas necessárias no desenvolvimento do conceito de função até termos hoje a linguagem algébrica e a representação analítica.

P4 aponta que a pesquisa histórica esclareceu, em relação ao conteúdo estudado, muitas dúvidas que extrapolam os aspectos estruturais, trazendo "um novo conjunto de compreensões" possibilitado pela história. O relato de P5 levanta um ponto importante, que é a relação entre a sua compreensão de questões relacionadas à trigonometria e as implicações dessa compreensão para seus alunos. Segundo ele, a história foi "decisiva" para o entendimento de várias relações presentes no estudo de trigonometria. 
P6 aponta a compreensão, possibilitada pelos estudos históricos, da representação no plano cartesiano dos números complexos, que, de acordo com ele, sem a história, configura-se apenas como uma regra mecânica. Além disso, alega que tal entendimento possibilitou dar outras explicações para seus alunos.

De acordo com os relatos, a pesquisa histórica proporcionou aos professores uma compreensão mais profunda dos conteúdos pesquisados. Isso ocorreu com todos os professores. Essa compreensão, além de referir-se aos conteúdos matemáticos propriamente ditos, como a trigonometria, as secções cônicas, números complexos, entre outros, possibilitou o entendimento dos porquês, dos fatos marcantes, dos impasses, e o encontro de algumas respostas que antes não tinham.

A compreensão do processo de construção do conhecimento, e não apenas do produto final, foi evidenciada nas falas dos sujeitos, que acrescentam que o estudo do processo pode minimizar a mera aplicação mecânica da Matemática.

Segundo alguns relatos, esse entendimento mais profundo dos conteúdos matemáticos influencia a prática pedagógica do professor, uma vez que ele se sente mais preparado para responder aos questionamentos dos seus alunos e com mais autonomia frente aos conteúdos.

Carvalho (2000) alega que a perspectiva histórica permite aos professores perceber que a maneira como um conceito é apresentado hoje é consequência das ideias anteriores, possibilitando observar a Matemática atual e a do passado, as diferenças nos usos das notações, terminologias, entre outros, proporcionando ao professor uma melhor compreensão conceitual.

Os dados evidenciaram que os professores sentiam falta de compreenderem mais a Matemática, os conteúdos matemáticos com os quais trabalham para poderem abordá-los com mais segurança na sala de aula.

A experiência vivenciada nos estudos históricos do conhecimento matemático, numa formação complementar, incorporou alguns elementos relevantes para suprir as necessidades formativas dos professores envolvidos.

- Categoria "Conhecimento relativo às adequações pedagógicas"

Esta categoria tem como objetivo analisar a necessidade de adequações pedagógicas aos estudos históricos realizados, com o intuito de possibilitar o uso da história da Matemática em sala de aula, ou seja, a necessidade de concatenar os vários aspectos oriundos da pesquisa histórica desenvolvida com elementos próprios da Pedagogia (BATISTA, 2009).

Em nossa compreensão, o processo de elaboração de uma abordagem pedagógica fundamentada na história da Matemática proporciona a integração entre o conteúdo 
matemático a ser abordado, os elementos históricos desse conteúdo e há a necessidade de várias adequações pedagógicas por parte do professor para tornar a abordagem adequada à realidade de uma sala de aula, colaborando para sua formação interdisciplinar.

$\mathrm{Na}$ análise do corpus, encontramos em todos os professores elementos que indicam a necessidade que os mesmos tiveram de realizar adequações pedagógicas para a implementação da abordagem em sala de aula, e os resultados apresentamos no quadro abaixo:

\begin{tabular}{|c|c|}
\hline \multicolumn{2}{|r|}{ Categoria "Conhecimento relativo às adequações pedagógicas" } \\
\hline $\mathrm{P} 1$ & $\begin{array}{l}\text { Mas uma coisa é a pesquisa histórica, é você fazer aquela pesquisa teórica, outra coisa é } \\
\text { fazer a transposição, a adequação didática dessa pesquisa possível de ser colocada em sala } \\
\text { de aula. } \\
\text { Qual é a adequação que você tem que fazer desse conteúdo, quais são os cuidados, o que é } \\
\text { essencial para sua pesquisa, para você adaptar de forma coerente, adequada para você levar } \\
\text { para a sala de aula. }\end{array}$ \\
\hline $\mathrm{P} 2$ & $\begin{array}{l}\text { [...] procurei sempre amarrar, fazer essa relação entre o que era história da matemática, } \\
\text { como foi desenvolvida a trigonometria nessa história e as atividades didáticas para que o } \\
\text { aluno também não ficasse [...] não ficasse cansativo para ele. } \\
\text { [...] as atividades tinham que ser também dinâmicas, uma atividade que estimulasse o aluno } \\
\text { para o aprendizado, não podia ser um texto histórico somente, tinha que ter adequações. }\end{array}$ \\
\hline P3 & $\begin{array}{l}\text { Pois eu tinha na mão muitas informações históricas, mas e aí, quais escolher? Como minha } \\
\text { intençáo era compor uma sequência de atividades para a aprendizagem de função, então isto } \\
\text { também estava presente na investigação histórica. } \\
\text { [...] organizar tudo isso de forma integrada é um grande desafio, é muito difícil conseguir } \\
\text { isso. Só fui perceber como é complexo o processo de construção de uma abordagem histórica } \\
\text { depois de fazer essa pesquisa, porque não é somente "pegar" a história da matemática e } \\
\text { contar na sala de aula. Não é isso, é necessário montar uma proposta possivel de ser } \\
\text { desenvolvida em turmas normais, com alunos comuns que encontramos todos os anos, e } \\
\text { montar uma proposta que contribua para a aprendizagem de conteúdos matemáticos, e não } \\
\text { se faz isso de qualquer forma, é necessária muita pesquisa. }\end{array}$ \\
\hline $\mathrm{P} 4$ & $\begin{array}{l}\text { [...] a maior dificuldade é selecionar, entre todos esses materiais históricos disponíveis, } \\
\text { aqueles que se adequam melhor aos objetivos da pesquisa. Quer dizer, o que usar? Como } \\
\text { usar essa parte histórica de forma pedagógica? Como relacionar a história com as } \\
\text { atividades de investigação em sala de aula? } \\
\text { Então não é só pegar o que os livros de história da matemática trazem, tem que selecionar os } \\
\text { trechos relevantes e, depois, adequá-los à proposta que está sendo desenvolvida, e isso não é } \\
\text { fácil. } \\
\text { Então eu selecionei recortes históricos que tinham algo prático, que pudesse ser "feito" pelo } \\
\text { aluno, como o método do jardineiro e de Kepler, que eram usados no século VI. }\end{array}$ \\
\hline P5 & $\begin{array}{l}\text { Como é que eu pego uma história que está formalizada nos textos acadêmicos e construo um } \\
\text { texto histórico para trabalhar com os alunos de forma mais didática. Isso se eu pensar em } \\
\text { trabalhar com algum texto. Já começa um problema aí, porque eu preciso saber fazer uma } \\
\text { transposição didática desse texto, do acadêmico para um texto para o aluno. }\end{array}$ \\
\hline
\end{tabular}




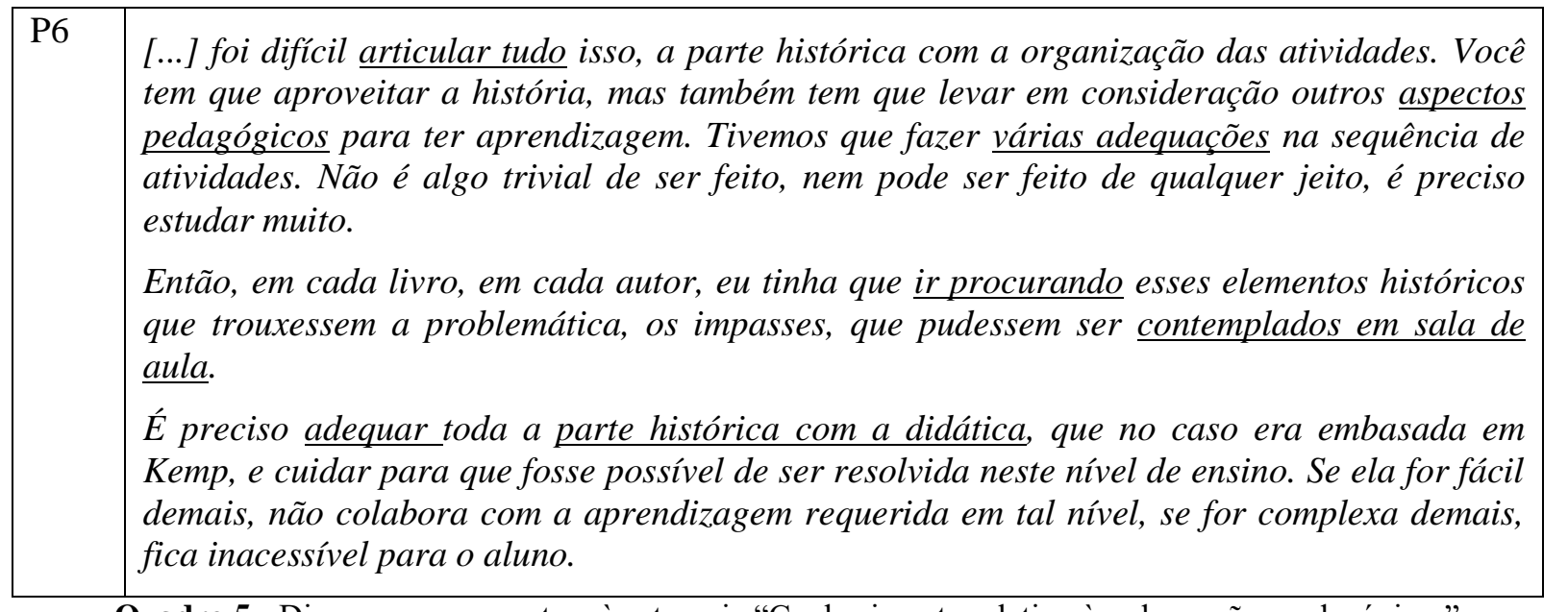

Quadro 5 - Discursos que remetem à categoria "Conhecimento relativo às adequações pedagógicas" Fonte: Araman (2011).

P1 apresenta, em sua fala, um ponto importante de ser observado, que também foi evidenciado por outros professores. Os dados, as informações provenientes da pesquisa teórica não podem simplesmente ser levadas para sala de aula. Segundo ele, são necessárias adequações coerentes dos estudos teóricos para que os mesmos possam ser usados em sala de aula.

Esse ponto também é levantado por P2, que considera não ser suficiente um texto histórico, são necessárias adequações para torná-lo passível de ser usado em sala de aula. Chama a atenção para o fato de que precisou "amarrar" as informações históricas da trigonometria com atividades didáticas, que fossem dinâmicas para não se tornarem cansativas aos alunos.

Para P3, que dispunha de muitas informações históricas, o desafio foi, dentre tantas opções, como proceder a seleção de forma que atendesse aos objetivos de sua pesquisa, que era a aprendizagem do conceito de funções. Evidencia, assim como os demais, que usar a história da Matemática em sala de aula vai muito além do que buscar informações históricas.

Como a perspectiva de P4 era desenvolver atividades de investigação apoiadas no desenvolvimento histórico, considerou importante selecionar, diante de muitos materiais históricos, aqueles mais adequados para relacionar com as atividades de investigação, que apresentam características mais práticas.

P5 utiliza o termo "transposição didática" ao referir-se à necessidade de adequar os textos históricos formalizados, acadêmicos, para serem usados nas salas de aula. Também aponta como uma tarefa difícil selecionar pontos que sejam relevantes e provoquem discussões profícuas com os alunos. 
$\mathrm{Na}$ opinião de P6, fazer todas as adequações necessárias para utilizar a história da Matemática em sala de aula não é algo trivial, exige muito estudo por parte do professor. Além disso, coloca que ainda foi necessário articular essas escolhas em relação à parte histórica com o embasamento didático que escolheu, respeitando o nível de desenvolvimento de seus alunos.

A construção de uma abordagem apoiada na história da Matemática evidenciou um caráter interdisciplinar, que integra e relaciona entre si conhecimentos conceituais, teóricos e metodológicos de diversas áreas.

Fica evidente, por meio da análise realizada, que os professores tiveram que articular elementos relativos à área da pesquisa em história da Matemática com os relacionados aos aportes didáticos. As opções vão desde a seleção, nos estudos históricos, dos elementos relevantes e adequados para cada conteúdo, cada nível de ensino. Além disso, esses elementos devem ser adaptados, didaticamente, para atender ao objetivo de proporcionar aprendizagem. Alguns fazem a opção pela resolução de problemas, outros por atividades práticas e dinâmicas, enfim, em cada opção, em cada escolha do professor, as adequações foram necessárias.

São muitos conhecimentos e saberes que os professores articulam nesse processo rico e complexo, e que, certamente, colaboram para a sua formação profissional, numa perspectiva holística, pois abrangem reflexões e tomadas de decisão sob vários aspectos.

Como os próprios sujeitos evidenciaram, o processo de construção de uma abordagem pautada na história da Matemática para ser aplicada em sala de aula não é um processo trivial. Ele se dá pela interface entre vários elementos e só é possível por meio de estudos teóricos e metodológicos sistematizados, como os vivenciados pelos sujeitos de nossa investigação.

\section{O processo de construção de abordagens históricas e o desenvolvimento de saberes interdisciplinares do professor de Matemática: algumas considerações}

No decorrer desta investigação, procuramos bases teóricas que discutissem a importância de estudos a respeito dos saberes docentes. Os autores que estudamos defendem que o professor, no exercício de sua profissão, elabora e reelabora diversos saberes na tentativa de lidar com as situações complexas de uma sala de aula.

Recorremos, ainda, a muitos estudos que evidenciam a relevância que a história da Matemática tem na formação do professor de Matemática. Muitas pesquisas salientam a importância de tais conhecimentos para essa formação, em seus vários aspectos, como já 
colocamos ao longo do texto. Entretanto, não encontramos pesquisas que procuram evidenciar como ocorre o processo de saberes do professor que desenvolve e aplica uma proposta histórica na Educação Matemática. É neste ponto que nossa investigação colabora com as pesquisas na área, estudando, de forma sistematizada, como se dá essa relação.

Em nosso entendimento, a vivência de realizar uma pesquisa em história da Matemática na qual o objetivo seja o de compor uma abordagem pedagógica aplicável em sala de aula proporciona ao docente uma formação que envolve muitos elementos, como conceituais, metodológicos e experienciais. Isso ocorre pelo fato de que, ao se propor a construir uma abordagem histórica, o professor, além de entrar em contato com a história do conteúdo matemático pesquisado, com os referenciais a respeito das potencialidades do uso pedagógico da história da Matemática, é envolvido num processo que demanda, a todo o tempo, escolhas, reflexões, articulações entre esses elementos e os aspectos pedagógicos.

É um processo criativo, que contribui para a construção de vários saberes, da autonomia do professor e da sua identidade profissional, uma vez que supera a perspectiva da racionalidade técnica, como descrita por Schön (1995), situando o professor como sujeito produtor de saberes e conhecimentos.

A literatura assinala como necessária a identificação dos saberes próprios do ensino, considerados em contextos reais, complexos, em que as variáveis não podem ser controladas. Gauthier et al. (1998) propõem que os saberes docentes devem ser estudados, explicitados e legitimados pelas pesquisas, mas que tenham como base as situações reais de ensino.

E este é o caso da nossa investigação, uma vez que procuramos explicitar saberes e conhecimentos produzidos pelos professores ao entrar em contato com a história da Matemática e ao construir uma abordagem pedagógica para usá-la em sala de aula. Os professores construíram e reconstruíram muitos saberes, que foram explicitados e estudados de forma sistematizada na análise dos dados de nossa pesquisa.

De acordo com a análise realizada, as categorias evidenciaram que os professores desenvolveram saberes relacionados ao entendimento dos conteúdos matemáticos, às potencialidades pedagógicas do uso da história da Matemática em sala de aula, à compreensão da natureza do conhecimento matemático e à necessidade de adequações pedagógicas para a aplicação da história da Matemática em sala de aula. Exige também o conhecimento prático do professor, pois é a partir da relação entre o conhecimento prático e as diversas opções teóricas e metodológicas que ele fará suas escolhas.

A figura 1 que apresentamos no início deste artigo evidencia o caráter interdisciplinar que envolve o processo de construção de uma abordagem histórica para o ensino de 
Matemática. Esse processo demanda muitos conhecimentos e, principalmente, a articulação e integração entre eles. Esse processo articulador e integrador que compreendemos ser relevante para a formação interdisciplinar do professor e se constitui no saber interdisciplinar (BATISTA, 2004).

O conhecimento escolar apresenta características interdisciplinares, uma vez que tal conhecimento não é uma mera simplificação do conhecimento científico disciplinar. Ao contrário, ele passa por diversas adequações que envolvem desde a elaboração do currículo até a prática pedagógica em sala de aula. Essas características interdisciplinares são similares às envolvidas no processo de construção de abordagens históricas, como já evidenciamos no texto.

Sendo assim, compreendemos que o viés interdisciplinar presente na construção de abordagens pedagógicas fundamentadas na história da Matemática enriquece a base de conhecimentos do professor. Esse processo é reflexivo e conduz o professor à capacidade de análise e síntese, buscando adequar os elementos teóricos e metodológicos disponíveis com a realidade da sala de aula, objetivando proporcionar a aprendizagem Matemática.

\section{Referências}

ALMEIDA, P. C. A.; BIAJONI, J. Saberes docentes e formação inicial de professores: implicações e desafios para as propostas de formação. Educação e Pesquisa, São Paulo, v. 33, n. 2, p. 281-295, mai./ago. 2007.

ARAMAN, E. M. O. Contribuições da história da matemática para a construção dos saberes do professor de matemática. 2011. 244f. Tese (Doutorado em Ensino de Ciências e Educação Matemática) - Centro de Ciências Exatas, Programa de Pós-Graduação em Ensino de Ciências e Educação Matemática. Universidade Estadual de Londrina, Londrina, 2011.

ARAMAN, E. M. O.; BATISTA, I. L. Contribuições da história da matemática para a construção dos saberes do professor de matemática. Bolema, Rio Claro, v. 27. n. 45, p. 1-30, abr. 2013.

BARBIN, E. Integranting history: research perspectives. In: FAUVEL, J.; MAANEN, J. (Org.). History in Mathematics Education: the ICMI study. Dordrecht: Ed. Kluwer Academic Publishers, 2000. p. 63-70.

BARDIN, L. Análise de Conteúdo. 3. ed. Lisboa: Ed. 70, 2004. 226 p.

BATISTA, I. L. Reconstruções histórico-filosóficas e a pesquisa interdisciplinar em educação científica e matemática. In: BATISTA, I.L.; SALVI, R. F. (Org.). Pós-graduação em Ensino de Ciências e Educação Matemática: um perfil de pesquisas. Londrina: Ed. EDUEL, 2009. p. 35-50.

BATISTA, I. L. O ensino de teorias físicas mediante uma estrutura histórico-filosófica. Ciência \& Educação, Bauru, v. 10, n. 3, p. 461-476, 2004. 
BATISTA, I. L.; LAVAQUI, V.; SALVI, R. F. Interdisciplinaridade escolar no ensino médio por meio de trabalho com projetos pedagógicos. Investigações em Ensino de Ciências, Porto Alegre, v. 13, n. 2, p. 209-239, 2008.

BATISTA, I. L.; LUCCAS, S. Abordagem histórico-filosófica e Educação Matemática - uma proposta de interação entre domínios de conhecimento. Educação Matemática Pesquisa, São Paulo, v. 6 , n. 1, p. 101-133, 2004.

BICUDO, M. A. V. Filosofia da educação matemática: um enfoque fenomenológico. In: BICUDO, M. A. V. (Org.). Pesquisa em Educação Matemática: concepções \& perspectivas. São Paulo: Ed. UNESP, 1999. p. 21-43.

BOGDAN, R.; BIKLEN, S. K. Investigação Qualitativa em Educação: uma introdução à teoria e aos métodos. 1. ed. Portugal: Porto, 1994. 336p.

BRITO, A.; ALVES, F. T. O. Profissionalização e saberes docentes: análise de uma experiência em formação inicial de professores de matemática. In: NACARATO, A. M.; PAIVA, M. A. V. (Org.). A Formação do Professor que Ensina Matemática: perspectivas e pesquisas. Belo Horizonte: Ed. Autêntica, 2008. p. 27-42.

BRITO, A. J.; CARVALHO, D. L. Utilizando a história no ensino de geometria. In: MIGUEL, A. et al. (Org.). História da Matemática em Atividades Didáticas. São Paulo: Ed. Livraria da Física, 2009. p. 13-104.

BROLEZZI, A. C. Conexões: história da matemática através de projetos de pesquisa. 1. ed. Rio Claro, São Paulo: SBHmat, 2003. (Coleção História da Matemática para professores). 32 p.

BURSAL, M. Turkish preservice elementary teachers' self-efficacy beliefs regarding mathematics and science teaching. International Journal of Science and Mathematics Education, Penang, v. 8, n. 4, p. 649-666, 2010.

CARVALHO, J. P. Brazil: the concept of function in in-service training. In: FAUVEL, J.; MAANEN, J. (Org.). History in mathematics education: the ICMI study. Dordrecht: Ed. Kluwer Academic Publishers, 2000. p. 137-142.

CHARALAMBOUS, C. Y.; PANAOURA, A.; PHILIPPOU, G. Using the history of mathematics to induce changes in preservice teachers' beliefs and attitudes: insights from evaluating a teacher education program. Educational Studies in Mathematics, New York, v. 71, n. 2, p. 161-180, 2009.

CURY, H. N.; MOTTA, C. E. M. História e estórias da matemática: uma entrevista com Heron nos dias atuais. In: CARVALHO, L. M. et al. (Org.). História e Tecnologia no Ensino da Matemática. Rio de Janeiro: Ed. Ciência Moderna, 2008. p. 77-96.

DASS, P. M. Understanding the nature of scientific enterprise (nose) through a discourse with its history: the influence of an undergraduate 'history of science' course. International Journal of Science and Mathematics Education, Penang, v. 3, p. 87-115, 2005.

FAUVEL, J.; MAANEN, J. Introduction. In: FAUVEL, J.; MAANEN, J. (Org.). History in Mathematics Education: the ICMI study. Dordrecht: Ed. Kluwer Academic Publishers, 2000. p. 1118.

FIORENTINI, D.; LORENZATTO, S. Investigação em Educação Matemática: percursos teóricos e metodológicos. 2. ed. Campinas: Autores Associados, 2007. (Coleção Formação de Professores). 228 p. 
FRIED, M. N. History of mathematics in mathematics education: a saussurean perspective. The Montana Mathematics Enthusiast, Missoula, v. 5, n. 2-3, p. 185-198, 2008.

FURINGUETTI, F. Teacher education through the history of mathematics. Educational Studies in Mathematics, Dordrecht, n. 66, p. 131-143, 2007.

GAUTHIER, C. et al. Por uma Teoria da Pedagogia: pesquisas contemporâneas sobre o saber docente. 2. ed. Ijuí: UNIJUÍ, 1998. 480 p.

GRUGNETTI, L.; ROGERS, L. Philosophical, multicultural and interdisciplinary issues. In: FAUVEL, J.; MAANEN, J. (Org.). History in Mathematics Education: the ICMI study. Dordrecht: Ed. Kluwer Academic Publishers, 2000. p. 38-62.

LAVAQUI, V.; BATISTA, I. L. Interdisciplinaridade em ensino de ciências e de matemática no ensino médio. Ciência \& Educação, Bauru, v. 13, n. 3, p. 399-420, 2007.

LIANG, L. L.et al. Preservice teachers' views about nature of scientific knowledge development: an international collaborative study. International Journal of Science and Mathematics Education, Penang, v. 7, n. 5, p. 987-1012, 2009.

LIU, P.H. History as a platform for developing college students' epistemological beliefs of mathematics. International Journal of Science and Mathematics Education, Penang, n. 7, p. 473 499, 2009.

LÜDKE, M.; ANDRÉ, M. E. D. Pesquisa em Educação: abordagens qualitativas. 1. ed. São Paulo: E.P.U., 1986. 99 p.

MARTINS, A. F. P. História e filosofia da ciência no ensino: há muitas pedras nesse caminho.

Caderno Brasileiro de Ensino de Física, Florianópolis, v. 24, n. 1, p. 112-131, abr. 2007.

MATTHEWS, M. História, filosofia e ensino de ciências: a tendência atual de reaproximação.

Caderno Catarinense de Ensino de Física, Florianópolis, v.12, n. 3, p. 164-214, dez. 1995.

MIGUEL, A. História, filosofia e sociologia da educação matemática na formação do professor: um programa de pesquisa. Educação e Pesquisa, São Paulo, v. 31, n. 1, p. 137-152, jan./abr. 2005.

MIGUEL, A.; MIORIM, M. A. História na educação matemática: propostas e desafios. 1. ed. Belo Horizonte: Autêntica, 2008. 198 p.

ROCHA, L. P.; FIORENTINI, D. Desenvolvimento profissional do professor de matemática no início de carreira no Brasil. Quadrante, Lisboa, v. 15, n. 1-2, p. 145-168, 2006.

SCHÖN, D. Formar professores como profissionais reflexivos. In: NÓVOA, A. (Org.). Os Professores e sua Formação. Lisboa: Ed. Dom Quixote, 1995. p. 77-91.

SHULMAN, L. S. Those who understand: knowledge growth in teaching. Educational Researcher, Washington, v. 15, n. 2, p. 4-14, 1986.

TARDIF, M. Saberes docentes e formação profissional. 1. ed. Petrópolis: Vozes, 2002. 325 p.

TZANAKIS, C.; ARCAVI, A. Integrating history of mathematics in the classroom: an analytic survey. In: FAUVEL, J.; MAANEN, J. (Org.). History in Mathematics Education: the ICMI study.

Dordrecht: Ed. Kluwer Academic Publishers, 2000. p. 201-240.

Submetido em Maio de 2016. Aprovado em Outubro de 2016. 